\title{
Pemphigus foliaceus in a sheep
}

\section{Pênfigo foliáceo em uma ovelha}

\author{
Aline Antas Cordeiro Cavalcanti ${ }^{1 *}$; Ana Claudia Campos ${ }^{2}$; Aline Guedes Mamede \\ de Moraes ${ }^{3}$; Clarice Ricardo de Macêdo Pessoa ${ }^{2}$; Franklin Riet-Correa ${ }^{4}$; \\ Marcia Almeida de Melo5; Edisio Oliveira de Azevedo ${ }^{6}$
}

\begin{abstract}
Pemphigus foliaceus (PF) is an autoimmune disease of the skin and is the most common form of pemphigus in domestic animals. This work reports a case of pemphigus foliaceus in a Santa Inês hair sheep. The ewe presented with multifocal bilateral crusted alopecic dermatitis affecting the chest, abdomen, and pelvic and thoracic limbs. Parakeratotic hyperkeratosis and acanthosis, in addition to subcorneal pustules, were observed histologically, and acantholytic cells and neutrophils were observed within the pustules. In the superficial and deep dermal tissues, there was intense eosinophilic infiltration and the presence of rare macrophages. These microscopic findings were characteristic of PF, and treatment with dexamethasone was ineffective. This disease is rare in sheep, and this is the first case report to be published in Brazil.
\end{abstract}

Key words: Pemphigus foliaceus. Sheep. Skin.

\section{Resumo}

Pênfigo foliáceo (PF) é uma doença autoimune da pele e é a forma mais comum de pênfigo em animais domésticos. Este trabalho relata um caso de pênfigo foliáceo em uma ovelha Santa Inês. A ovelha apresentava dermatite alopécica crostosa bilateral e assimétrica no tórax, abdômen, e membros pélvicos e torácicos. Hiperceratose paraqueratótica e acantose, além de pústulas subcorneais, foram observados histologicamente, e células acantolíticas e neutrófilos foram observadas dentro das pústulas. $\mathrm{Na}$ derme superficial e profunda, havia intenso infiltrado de eosinófilos e raros macrófagos. Os achados microscópicos são característicos de PF, e o tratamento com dexametasona foi ineficiente. Esta doença é rara em ovinos e este é o primeiro relato de caso a ser publicado no Brasil.

Palavras-chave: Pênfigo foliáceo. Ovino. Pele.

1 Discente, Doutorado do Programa de Pós-Graduação em Ciência e Saúde Animal, Universidade Federal de Campina Grande, UFCG, Patos, PB, Brasil. E-mail: aline.antas@hotmail.com

2 Prof ${ }^{\text {as }} \operatorname{Dr}^{\text {as }}$, Departamento de Medicina Veterinária do Sertão, Universidade Federal de Sergipe, UFS, Nossa Senhora da Glória, SE, Brasil. E-mail: anabutron@gmail.com; clarice_vet@ig.com.br

3 M.e, Programa de Pós-Graduação em Ciência e Saúde Animal, Universidade Federal de Campina Grande, UFCG, Patos, PB, Brasil. E-mail: alineguedesmamede@gmail.com

4 Prof., Dr., Departamento de Medicina Veterinária, Universidade Federal de Campina Grande, UFCG, Patos, PB, Brasil. Instituto Nacional de Investigación Agropecuaria (INIA), Estación Experimental INIA La Estanzuela, Ruta 50 Km 11, Colonia del Sacramento, Colonia, Uruguay. E-mail: franklinrietcorrea@gmail.com

5 Prof ${ }^{a}$, Dr $^{\mathrm{a}}$, Departamento de Medicina Veterinária, Universidade Federal de Campina Grande, UFCG, Patos, PB, Brasil. E-mail: almeidamelo@yahoo.com.br

6 Prof., Dr., Departamento de Medicina Veterinária, Universidade Federal de Sergipe, UFS, São Cristóvão, SE, Brasil. E-mail: eoazevedo@bol.com.br

* Author for correspondence 


\section{Introduction}

Pemphigus foliaceus (PF) is the most common form of pemphigus in domestic animals and has been described in dogs, cats, horses, and goats (SCOTT et al., 1983; MACÊDO et al., 2008). The occurrence of $\mathrm{PF}$ in small ruminants is rare, and there have been only five cases reported in goats (JACKSON et al., 1984; SCOTT et al., 1984; VALDEZ et al., 1995; PAPPALARDO et al., 2002; MACÊDO et al., 2008) and two cases reported in ewes (BRENNER et al., 2009; LAMBACHER et al., 2017).

$\mathrm{PF}$ is characterised by the production of autoantibodies against desmosomal antigens located within the intercellular spaces of the suprabasal layer of the epidermis. This immune response is directed against desmoglein, a $150-\mathrm{kDa}$ glycoprotein belonging to the cadherin family of adhesion molecules, and this protein represents the main antigen for PF in humans and the secondary antigen for PF in dogs (KOLOU et al., 1984; OLIVRY et al., 2006). Although the pathogenesis of the disease is not yet well understood, the production of autoantibodies against desmosomal antigens appears to be responsible for the destruction of intercellular bridges within the suprabasal epidermis as well as cell-cell separation (acantholysis) (PAPPALARDO et al., 2002).

Immunohistochemistry and direct immunofluorescence have been used to confirm the diagnosis of PF in domestic goats (JACKSON et al., 1984; VALDEZ et al., 1995; PAPPALARDO et al., 2002). Enzyme-linked immunosorbent assays (ELISA) and western blotting techniques have been developed to enable the detection of circulating antibodies (SCHMIDT; ZILLIKENS, 2010). The diagnosis of PF is generally performed according to the clinical history of the animal and the presence of characteristic histopathological lesions (BRENNER et al., 2009).

\section{Case Report}

The 10-month old Santa Ines ewe originated from a farm located at the Patativa do Assaré settlement, Santa Gertrudes District, Municipality of Patos, in the state of Paraíba, Brazil. The animal was raised with other sheep and goats but was the only animal observed to have chronic dermatitis for a period of one month.

A biopsy was performed using a scalpel and included a portion of the skin containing the lesion as well as a portion of the normal skin surrounding the lesion on the abdominal region. The specimen was fixed in $10 \%$ buffered formalin and then placed in paraffin. Skin sections were stained with haematoxylin and eosin (H\&E) for histological evaluation.

The animal received treatment with enrofloxacin ( $5 \mathrm{mg} / \mathrm{kg}$ body weight (bw), intramuscularly (IM), once per day) for 7 days and dexamethasone (0.1 $\mathrm{mg} / \mathrm{kg}$ bw, IM, once per day) for 14 days.

The ewe was in good overall condition upon clinical examination, although multifocal, bilateral, crusted alopecic dermatitis was observed on the thorax, abdomen, and pelvic and thoracic limbs upon dermatological examination. The lesions on the thoracic and pelvic limbs were pronounced and were characterised by greyish crusted lesions of various sizes that were well adhered to the skin (Figures 1A and B) as well as intense pruritus. Skin scrapings were negative for ectoparasites and fungi. The histopathological findings included an extensive focal area of parakeratotic hyperkeratosis and acanthosis, in addition to focal areas with subcorneal pustules (Figure 1C). Additionally, acantholytic cells and neutrophils were found within the pustules (Figure 1D). The superficial and deep dermal tissues demonstrated intense eosinophilic infiltration and the presence of rare macrophages.

The macroscopic skin lesions identified on the ewe in the current study differed from those 
described in the previous reports (JACKSON et al., 1984; SCOTT et al., 1984; PAPPALARDO et al., 2002; MACÊDO et al., 2008; VALDEZ et al., 1995; BRENNER et al., 2009), which had been characterised as crusted and exfoliative lesions. However, the histological lesions identified in the current study were similar to those previously described in goats (JACKSON et al., 1984; SCOTT et al., 1984; PAPPALARDO et al., 2002; MACÊDO et al., 2008) and ewes (BRENNER et al., 2009; LAMBACHER et al., 2017). The occurrence of a dermal eosinophilic infiltrate in cases of PF has been described in horses, dogs (VANDENABEELE et al., 2004; VAUGHAN et al., 2010) and goats (MACÊDO et al., 2008), and this observation is often associated with recent lesion formation. The current case represents the second report of PF in domestic sheep (Ovis aries).

Figure 1. An ewe with pemphigus foliaceus. A. Irregular areas of crusted alopecia on the thorax, abdomen, and thoracic and pelvic limbs. B. Areas of crusted alopecia on the thorax. C. Skin tissue sections showing parakeratotic hyperkeratosis and acanthosis as well as the presence of subcorneal pustules (arrow). Haematoxylin and eosin staining (H\&E) at 10x magnification. D. Skin tissue section showing a subcorneal pustule containing neutrophils and acantholytic cells (arrow). H\&E staining at 40x magnification.

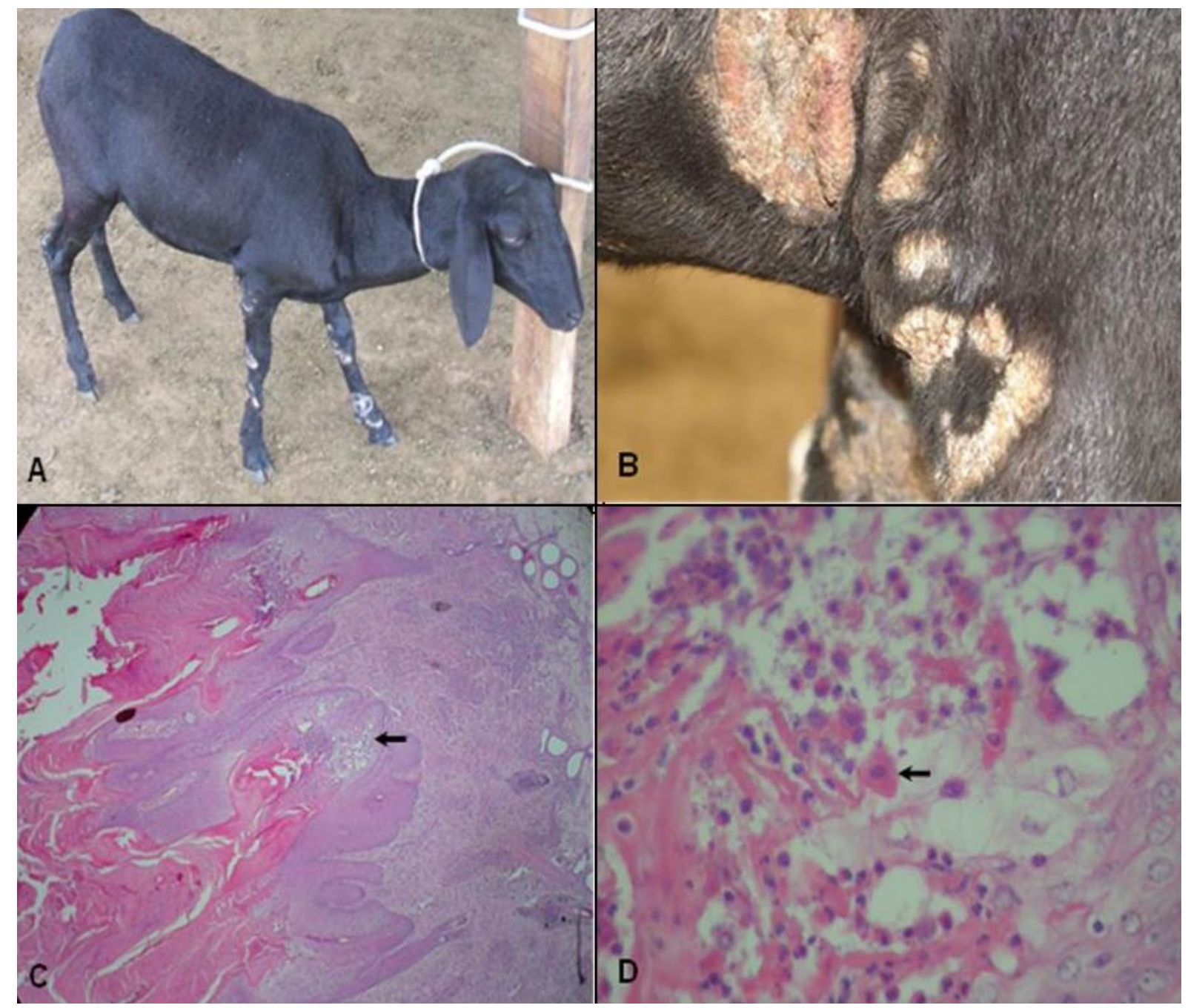


According to the owner, the lesions and pruritus decreased following treatment, although the animal experienced lethargy, depression, and weight loss and subsequently died. Unfortunately, a necropsy was not performed to determine the cause of death. PF treatment has been successful in goats through the use of intramuscular prednisolone (VALDEZ et al., 1995; PAPPALARDO et al., 2002), intravenous and intramuscular dexamethasone, intramuscular triamcinolone (SCOTT et al., 1984), and topical corticosteroid ointments (JACKSON et al., 1984). In addition, intramuscular aurothioglucose treatment was shown to be effective in one case (SCOTT et al., 1984) but ineffective in another (VALDEZ et al., 1995), and treatment with prednisolone (LAMBACHER et al., 2017) and triamcinolone was shown to be effective in sheep (BRENNER et al., 2009). Therefore, the administration of additional, non-steroidal immunosuppressive drugs for maintenance therapy would be desirable in future PF cases (PAPPALARDO et al., 2002).

In conclusion, $\mathrm{PF}$ is a rare autoimmune disease in sheep, which present with similar clinical and histopathological features as goats, and this report represents the first published case of PF in sheep in Brazil.

\section{References}

BRENNER, D. J.; STOKKING, L.; DONOVAN, T. A.; LAMBERSKI, N. Pemphigus foliaceus in a barbary sheep (Ammotragus lervia). Veterinary Record, London, v. 17, n. 165 , p. 509-510, 2009.

JACKSON, P. G. G.; LLOYD, S.; JEFFERIES, A. R. Pemphigus foliaceus in a goat. Veterinary Record, London, v. 114, n. 19, p. 479, 1984.

KOLOU, L.; KUSUMI, A.; STEINBERG, M. S.; KLAUS-KOVTUN, V.; STANLEY, J. R. Human autoantibodies against a desmosomal core protein in pemphigus foliaceus. Journal of Experimental Medicine, New York, v. 160, n. 5, p. 1509-1518, 1984.

LAMBACHER,B.;SCHOISWOHL, J.;BRUNTHALER, R.; WITTEK, T.; KRAMETTER-FRÖTSCHER, R. Successful treatment of pemphigus foliaceus in a Berrichon du Cher ram with methylprednisolone acetate.
Veterinary Dermatology, Oxford, v. 28, n. 5, p. 499-e117, 2017.

MACÊDO, J. T. S. A.; RIET-CORREA, F.; DANTAS, A. F. M.; SIMÕES, S. V. D. Pênfigo foliáceo em cabra Boer. Ciência Rural, Santa Maria, v. 38, n. 9, p. 26332635, 2008.

OLIVRY, T.; LAVOY, A.; DUNSTON, S. M.; BROWN, R. S.; LENNON, E. M.; WARREN, S. J.; PRISAYANH, P.; MÜLlER, E. J.; SUTER, M. M.; DEAN, G. A. Desmoglein-1 is a minor autoantigen in dogs with pemphigus foliaceus. Veterinary Immunology and Immunopathology, Amsterdam, v. 110, n. 3-4, p. 245255, 2006.

PAPPALARDO, E.; ABRAMO, F.; NOLI, C. Pemphigus foliaceus in a goat. Veterinary Dermatology, Oxford, v. 13, n. 6, p. 331-336, 2002.

SCHMIDT, E.; ZILLIKENS, D. Modern diagnosis of autoimmune blistering skin diseases. Autoimmunity Reviews, Amsterdam, v. 10, n. 2, p. 84-89, 2010.

SCOTT, D. W.; MANNING, T. O.; SMITH, C. A.; LEWIS, R. M. Pemphigus and pemphigoid in dogs, cats and horses. Annals of the New York Academy of Science, New York, v. 420, n. 1, p. 353-360, 1983.

SCOTT, D. W.; SMITH, M. C.; SMITH, C. A.; LEWIS, R. M. Pemphigus foliaceus in a goat. Agri-Practice, Santa Barbara, v. 5, n. 4, p. 38-45, 1984.

VALDEZ, R. A.; GELBERG, H. B.; MORIN, D. E.; ZUCKERMANN, F. A. Use of corticosteroids and aurothioglucose in a pygmy goat with pemphigus foliaceus. Journal of the American Veterinary Medical Association, New York, v. 207, n. 6, p. 761-765, 1995.

VANDENABEELE, S. I. J.; WHITE, S. D.; AFFOLTER, V. K.; KASS, P. H.; IHRKE, P. J. Pemphigus foliaceus in the horse: a retrospective study of 20 cases. Veterinary Dermatology, Oxford, v. 15, n. 6, p. 381-388, 2004.

VAUGHAN, D. F.; CLAY HODGIN, E.; HOSGOOD, G. L.; BERNSTEIN, J. A. Clinical and histopathological features of pemphigus foliaceus with and without eosinophilic infiltrates: a retrospective evaluation of 40 dogs. Veterinary Dermatology, Oxford, v. 21, n. 2, p. 166-174, 2010. 